\title{
Przyjemność seksualna pracownic agencji towarzyskich — definicje, warunki, konteksty
}

DOI: 10.19195/2083-7763.8.10

Historia prostytucji pokazuje, że doświadczenia cielesne kobiet świadczących usługi seksualne niemal zawsze stanowiły ciekawe zagadnienie dla prawodawców, Ojców Kościoła, badaczy, społeczników oraz wszelkich zainteresowanych.

Od czasów pierwszych definicji prostytucji, sformułowanych przez Solona i Ulpiana na potrzeby prawodawstwa starożytnej Grecji i Rzymu, kluczowym jej elementem, poza aspektem otrzymywania wynagrodzenia, było oddawanie przez kobietę swojego ciała do dyspozycji większej liczbie osób oraz brak możliwości wyboru partnera seksualnego ${ }^{1}$. Z perspektywy prawodawców, zgłębiających meandry tego pojęcia, ważne było więc podkreślenie, że stosunki seksualne odbywają się nie z tym, z kim chciałaby kobieta ze względu na odczuwane przez siebie pobudzenie $^{2}$, lecz potencjalnie z każdym, pomimo czy niezależnie od jej odczuć. Tym samym odczuwanie przez nią przyjemności seksualnej w kontekście relacji z klientami było być może nie niemożliwe, ale mało prawdopodobne.

Na temat doznań seksualnych „kobiet upadłych” wypowiadali się także Ojcowie Kościoła. W literaturze przedmiotu przywoływane są rozważania na temat prostytucji kanonika Tomasza z Chobham (XII wiek), który uznawał, że jeśli kobieta angażuje się w prostytucję z konieczności ekonomicznej, a nie z żądzy rozkoszy,

${ }^{1}$ M. Antoniszyn, A. Marek, Prostytucja w świetle badań kryminologicznych, Warszawa 1985, s. 8; M. Kuryłowicz, Prawne aspekty prostytucji w państwie rzymskim, [w:] Prostytucja, red. M. Mozgawa, Warszawa 2014, s. 21.

${ }^{2} \mathrm{~W}$ tym miejscu abstrahuję od rozważań na temat tego, jak przez wieki postrzegano potrzeby seksualne kobiet, a raczej jak zaprzeczano ich istnieniu. Należy jednak pamiętać, że w wielu okresach historycznych prostytutki traktowane były jako „specjalna” kategoria kobiet, o „spaczonym" popędzie, który przejawiał się tym, że były zdolne do odczuwania typowego dla mężczyzn pobudzenia seksualnego. 
to sprzedaje swoje ciało i wykonuje pracę. Dla oceny jej czynu najważniejsze było to, czy zarobiła pieniądze uczciwie, czyli nie oszukała klienta (na przykład zwodząc go co do swego prawdziwego wyglądu za pomocą stroju czy makijażu) ${ }^{3}$. Innymi słowy, jeśli motyw ekonomiczny był jedynym odpowiedzialnym za zaangażowanie się danej kobiety w prostytucję, mogła ona liczyć na pewne zrozumienie, przynajmniej ze strony cytowanego kanonika. Nie była to jednak dominująca perspektywa. Ojcowie Kościoła (między innymi święty Tomasz i święty Augustyn) surowo oceniali kobiety parające się prostytucją, ale jednocześnie akceptowali samą instytucję jako sposób na zaspokojenie potrzeb seksualnych mężczyzn (niezależnie od ich stanu cywilnego). Efektem tego rozdwojenia była niezwykle popularna wizja prostytucji jako „pałacowej kloaki”, która niezależnie od ogólnego nieprzyjemnego wrażenia jest niezbędna ${ }^{4}$, gdyż bez niej męskie „namiętności zakłócą wszystko" 5 .

Podobną perspektywę można zrekonstruować z prac pierwszych badaczy (nie tylko społecznych, lecz także na przykład lekarzy) oraz działaczy społecznych, którzy w XIX wieku zaczęli interesować się kobietami świadczącymi usługi seksualne. W tym kontekście warto wspomnieć o definicji Josefa Schranka, austriackiego lekarza z końca XIX wieku, który podkreślał, że podstawowym motywem „prawdziwej” prostytucji jest motyw zarobkowy. Kobiety nie można więc nazwać prostytutką, jeśli uprawia stosunki z licznymi partnerami dla osiągnięcia doznań

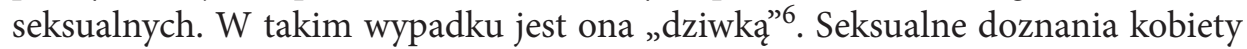
były zatem wskaźnikiem jej degeneracji.

Podobną perspektywę można odnaleźć $\mathrm{w}$ wielu koncepcjach z przełomu XIX i XX wieku, w których przyczyn prostytucji upatrywano w zaburzeniu instynktu monogamicznego właściwego kobietom (w przeciwieństwie do pierwotnych, poligamicznych skłonności mężczyzn $)^{7}$. Częstym tematem badań było także to, czy kobiety świadczące usługi seksualne są oziębłe seksualnie. Niektórzy z badaczy twierdzili, że cecha ta jest odpowiedzialna za angażowanie się w prostytucję, gdyż ułatwia kobietom przystosowanie się do codzienności tego „zawodu”; inni zaś utrzymywali, że jest jego skutkiem i konsekwencją instrumentalnego traktowania pożycia seksualnego ${ }^{8}$.

Również bardziej współczesne badania psychologiczne, pedagogiczne i socjologiczne poruszają kwestię tego, co odczuwają kobiety świadczące usługi seksualne. W tym miejscu chciałabym przywołać wyniki trzech projektów badawczych, zrealizowanych w Polsce w drugiej połowie XX i początkach XXI wieku, $\mathrm{w}$ odstępach około dwudziestoletnich. W każdym $\mathrm{z}$ nich autorzy pochylali się

\footnotetext{
3 J. Rossiaud, Prostytucja w średniowieczu, przeł. P. Salwa, Warszawa 1997, s. 134.

${ }^{4}$ M. Karpiński, Najstarszy zawód świata. Historia prostytucji, Berkshire 1997, s. 31.

5 J. Rossiaud, op. cit., s. 131.

${ }^{6}$ K. Imieliński, Manowce seksu - prostytucja, Łódź 1990.

7 J. Sztobryn-Giercuszkiewicz, Psychologiczne aspekty prostytucji, Łódź 2004, s. 36.

${ }^{8}$ M. Antoniszyn, A. Marek, op. cit., s. 61.
} 
nad zagadnieniem doznań seksualnych kobiet zaangażowanych w prostytucję, choć należy zaznaczyć, że wątek ten traktowany był przez nich raczej skrótowo.

Pierwszym z nich jest projekt kierowany przez Magdalenę Jasińską, zrealizowany wśród 100 młodych kobiet (do 25. roku życia) świadczących usługi seksualne (oraz odznaczających się innymi „symptomami demoralizacji”) w Warszawie lat pięćdziesiątych XX wieku ${ }^{9}$. Z badań wynika, że respondentek nie cechował, wbrew obiegowym opiniom, wybujały temperament seksualny. 30\% badanych kobiet było oziębłych seksualnie, co oznacza, że nie odczuwały żadnej satysfakcji nawet przy stosunkach z mężczyznami, z którymi łączyło je uczucie; $24 \%$ oceniało stosunki seksualne z klientami jako „raczej przykre przeżycie”, czerpały one jednak satysfakcję z życia seksualnego, jeśli z partnerem łączyła je więź uczuciowa. Natomiast $46 \%$ respondentek odczuwało satysfakcję, ale nie zawsze i nie z tym samym partnerem. Oznacza to, że odczuwały zadowolenie ze współżycia z mężczyznami, z którymi łączyły je „bliższe więzy”, a także z klientami, jeśli „im się podobali”. Wyniki te można podsumować słowami M. Jasińskiej: „problem przyjemności płynącej z życia płciowego jest u prostytutek dość skomplikowany"10. Wyjaśnienie tych wyników wymaga z pewnością więcej niż wskazania jednego czynnika (na przykład spaczenia popędu), jak czynili to wcześniejsi badacze.

Kolejnym projektem jest badanie zrealizowane przez kryminologów Michała Antoniszyna i Andrzeja Marka, przeprowadzone wśród 140 kobiet świadczących usługi seksualne w lokalach rozrywkowych w Trójmieście i Włocławku na przełomie lat siedemdziesiątych i osiemdziesiątych XX wieku. Analizując zgromadzone dane, autorzy stwierdzili, że seksualizm większości badanych kobiet był umiarkowany, a osoby nadpobudliwe seksualnie należały do rzadkości, podobnie jak oziębłe płciowo. Można więc zauważyć, że badacze generalnie zgadzali się z wnioskami M. Jasińskiej. Z ich analiz wynika także, iż wiele respondentek było żądnych doznań seksualnych i zaspokajało je w trakcie zarobkowania, lecz także z pozazarobkowymi partnerami. Badacze zauważyli, że niektóre z badanych kobiet były skłonne „pójść” z bardziej atrakcyjnym mężczyzną, który pociągał je seksualnie, nawet jeśli jego możliwości finansowe były gorsze niż klientów alternatywnych, ale obojętnych dla danej kobiety. Jednocześnie dla respondentek ważna była „ostrożność zawodowa” oraz dążenie do uniknięcia zbytniego „wyeksploatowania się" podczas kontaktu z jednym klientem, tak aby móc danego wieczora przyjąć kolejnych mężczyzn $^{11}$. Można więc zauważyć, że $\mathrm{z}$ badań tych wyłania się obraz kobiet, które w znacznym stopniu świadomie i celowo dobierały klientów nie tylko najbardziej zamożnych, lecz także odpowiadających ich wizji atrakcyjności i być może ich fantazjom i potrzebom seksualnym. Przynajmniej niektóre z badanych zaspokajały więc za pomocą prostytucji również swoje potrzeby seksualne.

\footnotetext{
9 M. Jasińska, Proces społecznego wykolejania młodocianych dziewcząt, Warszawa 1967.

10 Ibidem, s. 113-114.

11 M. Antoniszyn, A. Marek, op. cit., s. 61-62.
} 
Najbardziej współczesny projekt badawczy, o którym chciałabym wspomnieć, zrealizował Zbigniew Izdebski wraz z zespołem ${ }^{12}$ na próbie 400 kobiet świadczących usługi seksualne w różnych typach prostytucji w największych miastach Polski. Choć zagadnienie doznań seksualnych kobiet nie było przedmiotem tego badania, $\mathrm{z}$ wielu pytań, jakie zadawano respondentkom, rysuje się interesujący obraz zarówno komercyjnego, jak i prywatnego życia seksualnego badanych. Większość respondentek (70\%) miała dziennie od jednego do trzech klientów. Prawie co dziesiąta kobieta miała podczas typowego dnia pracy czterech klientów, zaś po $6 \%$ zadeklarowało, że przeciętnie ma pięciu klientów lub sześciu i więcej. Ponad dwie trzecie badanych przyznało, że w ostatnim tygodniu miało od jednego do dziesięciu klientów; 38\% — od jednego do pięciu, a 30\% — od sześciu do dziesięciu klientów. Natomiast 21\% zadeklarowało, że w ciągu ostatniego tygodnia miało więcej niż dziesięciu klientó $w^{13}$. Respondentki pytano także o ich ocenę sprawności seksualnej klientów na skali od jeden do pięć, gdzie jeden oznacza słabą, zaś pięć - bardzo wysoką sprawność seksualną klienta. Co druga respondentka (51\%) przyznała swoim klientom notę ' 3 ' na pięciostopniowej skali. Co piąta (20\%) przyznałaby im ' 4 ', pomimo iż wiele z nich regularnie było świadkami problemów seksualnych klientów, przede wszystkim zaburzeń wytrysku i erekcji ${ }^{14}$. Z kolei własne nastawienie do stosunków seksualnych z klientami może obrazować odpowiedź na pytania o problemy i trudności, jakie w ciągu ostatnich dwunastu miesięcy poprzedzających ankietę miały respondentki podczas komercyjnego stosunku seksualnego. Większość badanych kobiet (68\%) uskarżało się na suchość w pochwie podczas stosunku, a prawie co druga (47\%) podczas stosunku odczuwała ból narządów płciowych. 64\% respondentek czuło niechęć do współżycia, 39\% miało problemy z osiągnięciem orgazmu klienta, a $15 \%$ skurcz mięśni uniemożliwiający odbycie stosunku ${ }^{15}$. Można więc powiedzieć, że wiele $\mathrm{z}$ nich odczuwało przede wszystkim negatywne doznania i orgazmy z klientem były dla nich niecodziennym zjawiskiem.

W kwestionariuszu zawarto także pytania o prywatne życie seksualne kobiet zaangażowanych w prostytucję. W ciągu dwunastu miesięcy poprzedzających badanie większość respondentek (77\%) miała również innych partnerów seksualnych niż klienci. Byli to mężowie, kohabitanci i przygodni kochankowie ${ }^{16} .70 \%$ $(\mathrm{N}=366)$ respondentek deklarowała, że czuje się usatysfakcjonowana swoim prywatnym życiem seksualnym, z czego $22 \%$ oceniło je bardzo dobrze. Z kolei $17 \%$

12 Z. Izdebski, G. Bartosik, A. Kaliwoda, Zachowanie seksualne i wiedza na temat HIV/AIDS w grupie kobiet świadczących ustugi seksualne, raport TNS OBOP 2002, http://www.aids.gov. pl/badania_spoleczne/228/ (dostęp: 29.09.2014). Zob. też Z. Izdebski, Seksualność Polaków na początku XXI wieku. Studium badawcze, Kraków 2012, s. 560-591.

13 Z. Izdebski, G. Bartosik, A. Kaliwoda, op. cit., s. 52-53.

14 Ibidem, s. 65-67.

15 Ibidem, s. 76.

16 Ibidem, s. 68. 
raczej nie było z niego zadowolone, a $13 \%$ oceniło je jako bardzo złe ${ }^{17}$. Jednocześnie warto zaznaczyć, że wśród respondentek, które w ostatnim roku miały partnera seksualnego niepłacącego za seks, trzy na dziesięć kobiet nie miało z nim żadnego stosunku w okresie miesiąca poprzedzającego badanie. Spośród badanych kobiet, które w ciągu ostatniego miesiąca miały kontakty seksualne z partnerem niepłacącym za seks, $17 \%$ odbyło nie więcej niż cztery stosunki. Ponad dwadzieścia stosunków w tym czasie deklarowało 5\% badanych kobiet. Co istotne, odpowiedzi na to pytanie udzieliło 306 z 400 badanych $^{18}$. Może to oznaczać, że niektórym kobietom nie udaje się zbalansować intensywności prywatnego i komercyjnego życia seksualnego, a także iż na zaangażowaniu w prostytucję cierpi raczej prywatny seks. Jednocześnie jest to temat na tyle trudny, że niespełna jedna czwarta badanych wolała go nie zgłębiać.

Rozważając zagadnienie doświadczeń kobiet podczas komercyjnych stosunków seksualnych, należy także zwrócić uwagę na dodatkowe wątki. Jednym z nich jest zjawisko emocjonalnego odcinania się kobiet zaangażowanych w prostytucję od swojego ciała. W skrajnej formie zjawisko to przyjmuje postać dysocjacji, czyli opuszczania ciała, emocjonalnego separowania się od niego, gdy nie jest możliwe przerwanie traumatycznej interakcji. Zjawisko to jest często opisywane w literaturze $\mathrm{w}$ kontekście przemocy seksualnej i traktowane jako psychologiczny mechanizm obronny ${ }^{19}$. Jest ono również często wskazywane przez badaczy prostytucji jako sposób radzenia sobie z codziennością komercyjnych stosunków seksualnych ${ }^{20}$.

Innym mechanizmem stosowanym przez kobiety świadczące usługi seksualne jest odmienne wartościowanie oraz psychiczne rozdzielanie komercyjnego i prywatnego życia seksualnego. Jak zauważa Teela Sanders, dla większości badanych przez nią pracownic oferujących usługi seksualne w różnego rodzaju lokalach (odpowiednikach polskich agencji towarzyskich) seks z klientami miał inne znaczenie niż z kochankami, partnerami czy mężami. Szczególną rolę w różnicowaniu doznań $\mathrm{w}$ tych dwóch kontekstach odgrywała prezerwatywa, stosowana w komercyjnym i niestosowana w domowym życiu seksualnym, w którym była postrzegana jako bariera intymności i bliskości emocjonalnej. Przydawanie prezerwatywie negatywnych znaczeń $\mathrm{w}$ prywatnym seksie pomagało oddzielić i zróżnicować doświadczenia seksualne w życiu osobistym i zawodowym ${ }^{21}$.

17 Ibidem, s. 32.

18 Ibidem, s. 69.

19 M. Coy, „This body which is not mine”. The notion of the habit body, prostitution and (dis)embodiment, „Feminist Theory” 10, 2009, nr 1, s. 68; M. Farley, V. Kelly, Prostitution: A critical review of the medical and social sciences literature, „Women \& Criminal Justice” 11, 2000, nr 4, s. $29-64$.

20 M. Coy, op. cit., s. 68.

21 T. Sanders, The condom as psychological barrier: Female sex workers and emotional management, „Feminism \& Psychology” 12, 2002, s. 561-566. 
Kolejnymi technikami pomocnymi w oddzielaniu tych dwóch „światów” było: wyznaczanie stref ciała niedostępnych dla klientów - zastrzeżonych dla partnera/męża; niewykonywanie pewnych usług (na przykład namiętnych pocałunków), gdyż są one zarezerwowane dla prywatnego seksu; preferowanie świadczenia usług dominacji (w których bezpośredni kontakt cielesny jest ograniczony); definiowanie komercyjnego seksu jako pracy ${ }^{22}$.

Ważnym wątkiem jest także udawanie przez kobiety przyjemności seksualnej podczas spotkań z klientami. Choć według niektórych interpretacji jest to kolejny przejaw dysocjacji i odcinania się od swojego ciała ${ }^{23}$, wiele badaczek interpretuje udawanie jako element pracy emocjonalnej wykonywanej przez pracownice seksualne, która pozwala im radzić sobie $\mathrm{z}$ trudnymi emocjami ${ }^{24}$. Warto również zaznaczyć, że zdaniem niektórych autorów udawanie orgazmów i podniecenia seksualnego jest umiejętnością, której kolejne adeptki uczą się poprzez wysłuchiwanie opowieści koleżanek, oglądanie materiałów pornograficznych oraz odgrywanie roli prostytutki podczas komercyjnych stosunków seksualnych ${ }^{25}$. W tym sensie dla wielu (a może nawet większości) kobiet prostytucja (czy raczej praca seksualna) nie jest prostym przeniesieniem prywatnych relacji seksualnych w komercyjny kontekst, a raczej swego rodzaju występem, naznaczonym genderowo oraz seksualnie, który różni się od sposobów doświadczania własnej cielesności w innych kontekstach $^{26}$.

Ten krótki przegląd literatury przedmiotu pozwala zauważyć, że zagadnienie doświadczeń seksualnych, a ściślej ewentualnej przyjemności kobiet płynącej z komercyjnych relacji seksualnych jest przedstawiane w zróżnicowanym kontekście teoretycznym oraz nierzadko powiązane $\mathrm{z}$ oceną. Choć omówione badania wskazują na to, że doświadczenia kobiet w tym zakresie są różne, brakuje pogłębionej analizy, skąd te różnice mogą wynikać. Niniejszy artykuł jest próbą wskazania warunków, które wpływają na to, jak kształtują się doznania kobiet podczas komercyjnych stosunków seksualnych. Jest to o tyle ważne, że zagadnienie to dotyka istoty zjawiska prostytucji i może pomóc lepiej zrozumieć decyzje kobiet odnośnie do przebiegu i sposobu realizowania kariery ${ }^{27} \mathrm{w}$ prostytucji.

22 T. Sanders, 'It's just acting': Sex workers' strategies for capitalizing on sexuality, „Gender, Work and Organization" 12, 2005, nr 4, s. 325-326; M. O'Neill, Researching prostitution and violence: Towards a feminist praxis, [w:] Women, Violence and Male Power, red. M. Hester, L. Kelly, J. Radford, London 1996, s. 130-147; J. Davidson O'Connell, Prostitution, Power and Freedom, Cambridge 1998.

${ }^{23}$ M. Coy, op. cit., s. 69.

24 T. Sanders, 'It's just acting'..., s. 328.

${ }^{25}$ Ibidem, s. 330.

26 Ibidem, s. 329.

27 Pojęciem kariery posługuję się za przedstawicielami symbolicznego interakcjonizmu: H. Becker, Outsiderzy Studia z socjologii dewiacji, przeł. O. Siara, Warszawa 2009; E. Goffman, Instytucje totalne. O pacjentach szpitali psychiatrycznych i mieszkańcach innych instytucji totalnych, przeł. O. Waśkiewicz, J. Łaszcz, Sopot 2011; E. Hughes, Careers, „Qualitative Sociology” 20, 
Analizie zostały poddane wypowiedzi kobiet pracujących w agencjach towarzyskich dotyczące tego, co odczuwają (a czego nie) podczas kontaktów z klientami. Przedmiotem badania są także ich objaśnienia i uzasadnienia, które w kontekście wywiadu (a więc spotkania normalsa i osoby zdyskredytowanej, używając pojęć Ervinga Goffmana ${ }^{28}$ ) budują rozmówczynie. Z tego względu kluczowym obszarem dociekań jest nie tyle to, co n a p raw d ę czują, ile w jaki sposób społecznie (zarówno w grupie współpracownic agencji, jak i w społeczeństwie, transmitowane za pomocą socjalizacji) konstruowane są reguły odczuwania w tym kontekście.

Podstawę empiryczną niniejszego artykułu stanowią wywiady swobodne, przeprowadzone z 45 kobietami świadczącymi usługi seksualne w agencjach towarzyskich. Kobiety te miały od 18 do 60 lat. Ich staż pracy w agencjach towarzyskich wynosił od miesiąca do kilkunastu lat. Wywiady zostały nagrane na dyktafon (a następnie poddane transkrypcji zgodnie z zaleceniami Blake Polanda ${ }^{29}$ ) lub (w wypadku braku zgody na nagrywanie) spisane $\mathrm{w}$ formie notatek podczas trwania wywiadu. W artykule wykorzystane zostały te fragmenty wywiadów, w których rozmówczynie odnosiły się do kwestii doznań odczuwanych w trakcie komercyjnych stosunków seksualnych. Zostały one zakodowane zgodnie z zasadami kodowania otwartego, a następnie selektywnego, $\mathrm{w}$ ramach metodologii teorii ugruntowanej ${ }^{30}$. W artykule zaprezentowane zostały wybrane kategorie wywodzące się z tej analizy.

\section{Satysfakcja seksualna kobiet pracujących w agencjach towarzyskich}

Rozmówczynie, omawiając w trakcie wywiadów swoje doznania podczas stosunków seksualnych z klientami, zamykały je w trzech głównych kategoriach, które są jednocześnie kodami in vivo: „tu nie ma żadnej przyjemności”, „czasami się zdarza, ale to dlatego, że”, „tutaj się zarobi, a jeszcze mam przyjemnośc”. Zostaną one zaprezentowane poniżej, wraz z warunkami ich występowania.

1997, nr 3, s. 389-397; K. Konecki, Praca w koncepcji socjologii interakcjonistycznej, „Studia Socjologiczne" 1, 1988, nr 108, s. 225-245.

28 E. Goffman, Piętno. Rozważania o zranionej tożsamości, przeł. A. Dzierżyńska, J. Tokarska-Bakir, Gdańsk 2005.

29 T. Rapley, Analiza konwersacji, dyskursu i dokumentów, przeł. A. Gąsior-Niemiec, Warszawa 2010, s. 111-113.

30 B. Glaser, A.L. Strauss, Odkrywanie teorii ugruntowanej, przeł. M. Gorzko, Kraków 2009; A. Strauss, J. Corbin, Basics of Qualitative Research, London 1990. 


\section{„Tu nie ma żadnej przyjemności”}

Zdanie to, w podobnej lub identycznej formie, było jednym $z$ najczęściej powtarzanych przez rozmówczynie w kontekście ich doświadczeń podczas stosunków seksualnych z klientami. Jego analiza zwraca uwagę na dwie kwestie. Po pierwsze, wypowiadające je kobiety nie odczuwały żadnych pozytywnych doznań, przede wszystkim przyjemności seksualnej. Po drugie, tego typu reakcje dotyczą „tu”, a więc interakcji w kontekście komercyjnym (na terenie agencji oraz podczas tak zwanych wyjazdów - w mieszkaniu klienta lub wynajętym przez niego pokoju hotelowym). Poniżej szerzej opiszę oba te aspekty.

Wskazując na powody, dla których odczuwanie przyjemności seksualnej jest niemożliwe, badane kobiety wymieniały przede wszystkim brak więzi (pozytywnych uczuć, miłości) z klientem, co owocowało brakiem podniecenia seksualnego:

Nie przynosi to żadnej przyjemności, wiesz, inaczej to wygląda z kimś, kto jest obcy, a inaczej ze swoim jakimś mężczyzną, tu musimy używać nawilżaczy, wszystko jest suche, kobieta się nie podnieca, bo ten facet na nią nie działa, wcale nie działa, to musi po prostu różnych wspomagaczy używać. Bo jeśli nie, to to jest straszny ból, kobiety się zacierają, i dlatego się tych nawilżaczy używa. [k, 40 lat, 3 lata pracy w agencji]

Jak zauważa część rozmówczyń, nawet jeśli klient jest przystojny, obojętność emocjonalna oraz brak wiedzy o preferencjach seksualnych partnerki uniemożliwia satysfakcjonujący kontakt seksualny. W doświadczeniu wielu kobiet kontakty seksualne z klientami były całkowicie odarte z jakichkolwiek emocji, traktowane jako sekwencja ruchów i konkretnych czynności, prowadząca do satysfakcji klienta, ale z pewnością nie pracownicy agencji:

Nie ma żadnych przyjemności. Nie ma absolutnie żadnych. Tutaj jak taka taśma. [...] To jest taśmowa praca. Rozkładasz nogi, „heja” - myślisz, patrzysz w sufit i do widzenia. Taśma. Nie ma absolutnie żadnej przyjemności, chociaż może przyjść tu naprawdę bardzo przystojny facet, no i co z tego? Ja go nie kocham, on może jest przystojny, ale nie jest w stanie zrobić mi tak dobrze i nie podoba mi się aż tak bardzo, jak mój mąż na przykład. Jest sobie jakiś gościu, który przyszedł. I to jest wszystko. Daje, płaci mi i na razie, czekam na następnego klienta. Nie ma absolutnie żadnej przyjemności. [k, 30 lat, 9 lat pracy w agencji]

Pracownice stosowały metafory taśmy (a więc porównywały ją do pracy przy taśmie montażowej) czy pracy zawodowej, w której wykonywane czynności mają jedynie profesjonalny, a nie emocjonalny charakter:

Tutaj jest praca, ja tutaj w życiu nie miałam orgazmu i nie będę miała. [k, 22 lata, 3 lata pracy w agencji]

Oprócz redefiniowania swojego zaangażowania $\mathrm{w}$ prostytucję $\mathrm{w}$ kategoriach pracy badane stosowały także wiele innych technik ułatwiających im emocjonalne odcięcie się od swoich ciał i nieodczuwanie ich podczas stosunku z klientem. Były to między innymi: 
- selekcjonowanie akceptowanych pozycji i czynności seksualnych poprzez usuwanie klienta z pola percepcji (preferowanie pozycji, podczas których nie trzeba patrzeć na klienta);

- minimalizowanie kontaktu cielesnego z klientem;

- prowokowanie myśli oddalających "tu i teraz”;

- przyjmowanie środków psychoaktywnych.

Poniżej prezentuję wybrane cytaty stanowiące ilustracje wymienionych technik:

Na pewno to nie jest przyjemne, tak? Seks z mężczyzną, z którym jesteś, a seks z mężczyzną, który przychodzi dopiero co, to nie jest nic dobrego. Myślisz o czymś innym, starasz się myśleć przynajmniej o czymś innym, patrzysz na czas, na zegarek, kiedy się to skończy, bo tu są godziny i półgodziny tak? I największa frajda jest $\mathrm{z}$ tego, jak jest koniec. Każda ci to powie. [...] Nie ma to różnicy, każda patrzy na to jednakowo, nawet może być nie wiadomo kto, model nie wiadomo jaki. [k, 33 lata, 2 lata pracy $w$ agencji]

Ja się nie całuję, oni już wiedzą, że nie ma takiej opcji. Najlepiej jest, jak nie muszę się nawet rozbierać, tylko wiesz, szybko na chwilę się zdejmie majtki i już. Bez żadnego tam dotykania całego ciała czy leżenia na sobie czy tam kąpieli wspólnych. Nic z tych rzeczy. To to ja sobie robić mogę $\mathrm{z}$ mężem $\mathrm{w}$ domu. [k, 30 lat, 1,5 roku pracy w agencji]

Tu żadnej przyjemności nie masz, żadnej. Ja na przykład [...] yy działam se coś tam z facetem, zawsze najlepiej od tyłu, bo wtedy go nie widzę, patrzę sobie w kaloryfer. [k, 30 lat, 9 lat pracy w agencji]

Należy także zaznaczyć, że w wypadku niektórych kobiet w grę wchodziło nie tyle nieodczuwanie satysfakcji seksualnej, co odczuwanie skrajnie negatywnych emocji związanych z kontaktem z klientem:

To, co się dzieje na pokoju, można nazwać półgwałtem. [...] Dla mnie przynajmniej półgwałt. Słuchaj, przyjdzie tutaj, nie znasz kogoś, tak, widzisz go dziesięć minut i idziesz z nim do łóżka, to co to jest? Musisz, a nie chcesz. Nie musisz, a musisz, no to co to jest? Prawie że gwałt. Tylko bez obrony. To jest to samo. Dokładnie. Niczym się nie różni. Ja tak to odczuwam. Nie wiem jak ktoś inny. Ale ja tak. [k, 25 lat, 2 lata pracy w agencji]

W takich przypadkach proces odcinania się od swojego ciała można interpretować jako niemal niezbędny warunek tego, by kontynuowanie pracy w agencji było możliwe do zniesienia przez daną kobietę. Aby go osiągnąć, niektóre kobiety „znieczulały się,, przyjmując substancje psychoaktywne, inne odłączały się od ciała (dysocjacja). Ten sposób doświadczania ciała typowy był przede wszystkim dla początkujących pracownic, w pierwszym okresie ich pracy. Jest to czas, kiedy nakłada się na siebie wiele niekorzystnych dla nowicjuszki warunków: negatywny obraz siebie, wyrzuty sumienia i poczucie łamania norm społecznych po rozpoczęciu pracy, nieumiejętność radzenia sobie z klientami i reagowania na niewłaściwe (na przykład agresywne) zachowania z ich strony, brak zbudowanych mechanizmów obronnych, które ułatwiałyby poradzenie sobie w tej sytuacji. Niemniej jednak wypracowane w tym okresie sposoby radzenia sobie $\mathrm{z}$ własnymi emocjami (na przykład uciekanie się do zażywania substancji psychoaktywnych) mogą pozostać trwałą dyspozycją, trudną do zmiany w dalszym toku pracy w agencji. 
Niezależnie od prawdziwych odczuć kobiet świadczących usługi seksualne, aby mogły one maksymalizować swoje zarobki, powinny wywoływać w kliencie wrażenie możliwie autentycznego zaangażowania w interakcję. Klienci oczekują, że pracownica będzie współuczestniczyć w stosunku nie tylko ciałem, ale będzie aktywną partnerką, spontanicznie reagującą na przebieg spotkania. W obliczu emocjonalnej obojętności pracownic kluczową umiejętnością jest udawanie orgazmów, które pozwala pracownicy realizować strategie odcinania się od ciała w sposób możliwie mało zauważalny dla klienta:

Dla mnie to jest obojętne. Ja staram się okazywać, że już mam cztery orgazmy, jak klient na przykład nie może dojść. Ja wrzeszczę, no może nie wrzeszczę, ale jęczę, po prostu pomagam jemu, żeby go zadowolić, żeby SZYBCIEJ. Ale dla mnie to jest obojętne. Ja nie zakochałam się jeszcze $\mathrm{w}$ kliencie, nie miałam, nie wiem, orgazmu z klientem, [...] byłam $\mathrm{z}$ bardzo znanym dziennikarzem, bardzo znanym [...] i ja po prostu zawsze, jak tylko oglądałam jakieś relacje z nim, i to jeszcze jak nie miałam pojęcia, co to są kluby, agencje i prezerwatywy, i po prostu zawsze dreszczyk emocji był na mojej skórze, ale ten dreszczyk emocji, jak tylko się on tu pojawił, nagle opadł. Nie, po prostu nie. Ja przez te kilka lat NIE DOSTAŁAM orgazmu z klientem. Ja udaje, że TAK, ja udaję, że trzy-cztery razy, tak, „oczywiście kochanie, aaaa”, jęczę jak na wezwanie, ale ja tylko po prostu udaję to. [k, 38 lat, 5 lat pracy w agencji]

Warto zaznaczyć, że skuteczne udawanie może być źródłem przekonań współpracownic o tym, że dana kobieta faktycznie odczuwa orgazm, choć (zgodnie z jej deklaracjami) tak nie jest. Z drugiej strony porady, jak skutecznie udawać, są ważnym elementem socjalizacji zawodowej nowicjuszki w gronie bardziej doświadczonych pracownic ${ }^{31}$. Udawanie, szczególnie jeśli ma być przekonujące dla klienta, nie jest łatwym zadaniem. Im mniejsze doświadczenie pracownicy i silniejsze, negatywne emocje związane ze świadczeniem pracy seksualnej oraz interakcją z konkretnym klientem, tym trudniej jest pracownicy podjąć próby udawania. Opisane wcześniej skrajnie negatywne definicje prostytucji (jako półgwałt) praktycznie je uniemożliwiają.

Cytowane wypowiedzi pracownic pozwalają także zauważyć, że stosunki z klientami były często przeciwstawiane doświadczeniom seksu z partnerem $\mathrm{w}$ ich życiu prywatnym (dotyczy to kobiet, które w momencie wywiadu lub w przeszłości prowadziły pozaagencyjne życie seksualne). Rozmówczynie wielokrotnie zapewniały, że mają satysfakcjonujące życie seksualne, w którym oboje partnerzy czują się zaspokojeni zarówno pod względem seksualnym, jak i odczuwanej bliskości. Dopiero seks z własnym mężem czy partnerem był „prawdziwym seksem”, w którym obecne było obustronne podniecenie, zainteresowanie oraz troska o doznania i orgazm partnera. Pozwalałoby to sądzić, że kontekst komercyjny nie ma większego wpływu na praktyki seksualne kobiet w ich życiu osobistym. Z drugiej jednak strony niektóre z rozmówczyń wskazywały pewne niekorzystne konsekwencje dla

31 I. Ślęzak, Kolektywny wymiar budowania zaangażowania w pracę seksualną kobiet świadczacych ustugi seksualne w agencjach towarzyskich, „Przegląd Socjologii Jakościowej” 10, 2014, nr 4, s. 56-79; eadem, Praca kobiet świadczących ustugi seksualne w agencjach towarzyskich, Łódź 2016. 
ich prywatnego życia seksualnego. Było to przede wszystkim zmęczenie, znużenie seksem, traktowanie go jako obowiązku (uprawianie seksu z mężem/partnerem, by zapobiec jego zdradzie) lub też traktowanie seksu instrumentalne, aby uspokoić jego podejrzenia (jeśli nie wie o pracy w agencji) czy upewnić, że między nimi nic się nie zmieniło (jeśli wie o pracy $\mathrm{w}$ agencji). $\mathrm{W}$ każdym $\mathrm{z}$ tych przypadków seks „domowy”, mimo że partnerem była osoba uznawana za bliską, z którą pracownicę łączyły więzi uczucia i bliskości, przypomina pod niektórymi względami seks „agencyjny”. Niekoniecznie bowiem wiąże się z pozytywnymi odczuciami kobiety - w niektórych wypadkach przymusza się ona do stosunku, nie chcąc ryzykować pogorszeniem relacji z partnerem.

\section{„Czasami się zdarza, ale to dlatego, że”}

W wypadku niektórych rozmówczyń obok dominującej narracji opisanej powyżej pojawiały się uzupełniające ją objaśnienia. Ich celem jest wyjaśnienie sytuacji, gdy pracownica odczuwała jednak pewne pozytywne doznania podczas stosunku z klientem. Wytłumaczenia te, co warto zauważyć, występowały w każdym przypadku, co oznacza, że żadna z rozmówczyń nie chciała pozostawić bez własnej interpretacji tego, że zdarza się jej odczuwać satysfakcję seksualną podczas kontaktu z klientem. Objaśnienia te odwoływały się przede wszystkim do wyjątkowych, incydentalnych warunków, które spowodowały, że pracownica poczuła coś w trakcie spotkania. Wśród nich dominowały wskazania, że dany klient był inny niż wszyscy, miły, sympatyczny, bardzo przystojny, w „ich typie”. Niektóre rozmówczynie za niespodziewane orgazmy z klientami obwiniały ciało i jego "naturę". Zdaniem kobiet biologicznie jest ono tak zaprojektowane, że w określonych warunkach („chemia”, „przyciąganie”, „dopasowanie się" partnerów seksualnych) odczuwa przyjemność. Biologiczna natura ciała w określonych sytuacjach nie pozostawia więc miejsca na świadomie kontrolowanie swoich odczuć. W tego typu wyjaśnieniach ciało jest przedstawiane jako do pewnego stopnia autonomiczne, niepodlegające mechanizmom kontroli i kierowania przez umysł:

Zdarza się, że dziewczyna coś do klienta poczuje, jak jest ładny i tego i nawet w łóżku jest taki, no to ci powiem, że czasami się tego, się dopasowali facet z dziewczyną, i jest dobrze im. I wtedy, wiesz, nie musi wtedy tak myśleć, wiesz, tylko to tak samo idzie to tym uczuciem i to wtedy pomaga $w$ takiej sytuacji. [k, 28 lat, 10 lat pracy w agencji]

Warto zatem zauważyć, że rozmówczynie podczas wywiadu starały się zaprezentować jako osoby, które „nie są winne” tym „chwilom słabości”. To wyjątkowe okoliczności sprawiły, że zdarzyło się im doświadczyć tego, czego nie powinny (czyli przyjemności seksualnej). Zgodnie z dominującymi w badanej grupie przekonaniami „właściwym” wzorem zachowania w sytuacji komercyjnego stosunku seksualnego jest opisany wcześniej wzór braku odczuć seksualnych. 
Jest on pozytywnie wartościowany przez współpracownice jako oznaka „poprawnego" rozdzielania życia agencyjnego i prywatnego. Orgazm z klientem stanowi zaburzenie tej granicy, może świadczyć o traktowaniu prostytucji nie tylko w kategoriach pracy i wiązać się z posądzeniem danej kobiety przez współpracownice na przykład o nimfomanię. Tak więc nawet w kontekście agencji towarzyskiej można pozostać dla jej społeczności „porządną dziewczyną” lub „dziwką”. Z tej perspektywy nie powinno dziwić, że najrzadziej w wywiadach pojawiały się relacje o częstym czy regularnym doświadczaniu przez pracownice satysfakcji seksualnej. Niemniej jednak tego typu sytuacje były obecne.

\section{"Tutaj się zarobi, a jeszcze mam przyjemność"}

W przeprowadzonych wywiadach jedynie trzy kobiety deklarowały, że wielokrotnie (bardzo często, prawie zawsze) doświadczają z klientami pozytywnych doznań, łącznie $\mathrm{z}$ orgazmami. W przeciwieństwie do kobiet realizujących wcześniej opisany wzór incydentalnego odczuwania przyjemności seksualnej w tym wypadku rozmówczynie nie objaśniały swoich doznań zewnętrznymi warunkami. Zwracały za to uwagę, że celowo, świadomie koncentrowały się na sobie i swoich odczuciach, by je multiplikować. Był to dla nich sposób na zwiększenie swoich „korzyści” z prostytucji, gdyż obok zysku finansowego odczuwały także satysfakcję z seksu.

A tutaj się zarobi, a jeszcze mam przyjemność [śmiech], tak jak ja do tego podchodzę, bo ja tak jak powiedziałam, ja mam $z$ tego przyjemność też. [k, 35 lat, 3 lata pracy w agencji]

Dla kolejnej badanej był to również sposób na radzenie sobie z negatywnymi doznaniami związanymi z pracą seksualną. Inne podejście do seksu z klientem (na przykład odcinanie się od swojego ciała) traktowała ona jako zwiększające traumę, niepomagające się z nią uporać. Poszukiwanie pozytywów w pracy seksualnej postrzegała jako krok w stronę psychicznego przepracowania negatywnych doświadczeń oraz znalezienia swojej drogi, by przetrwać w prostytucji, w miarę możliwości nie angażując się w destrukcyjne zachowania (przykładowo przyjmowanie środków psychoaktywnych).

Ja to staram się traktować jako przyjemność, bo gdybym traktowała to jako przymus, no to ja bym już naprawdę psychicznie ZWARIOWAŁA [wzdycha]. [k, 39 lat, 2 lata pracy w agencji]

Ciekawe jest zestawienie prywatnych i komercyjnych kontekstów seksu w przypadku badanych reprezentujących ten sposób doświadczania przyjemności seksualnej. Respondentki deklarowały raczej udane życie seksualne ze swoim mężem czy partnerem. W ich wypowiedziach skłonność czy zdolność do odczuwania satysfakcji seksualnej miała charakter transkontekstualny i sprzyjała udanemu pożyciu niezależnie od tego, czy miało ono komercyjny, czy romantyczny charakter. 
W ich ocenie jest to bowiem pewna biologiczna, naturalna cecha zdrowych, normalnie rozwiniętych kobiet:

Ale jak się można wyłączyć? Ja nie potrafię się wyłączyć z niczego. No przecież coś przeżywam, to jak ja się mam wyłączyć? Nie wiem, jak się można wyłączyć. No nie potrafię, no. [k, 35 lat, 3 lata pracy w agencji]

Jedynym wyjątkiem od tego wzoru były sytuacje, gdy to partner czy mąż nie potrafił zaspokoić kobiety. W grę wchodziły tutaj zarówno brak umiejętności, jak i specyficzna postawa partnera (na przykład poczucie kobiety, że była w związku niedoceniana, że partner ją zdradzał). W takim wypadku seks agencyjny mógł być przez nie oceniany nawet wyżej niż domowy.

Mój mąż nie bardzo potrafił zaspokoić kobietę, mnie przynajmniej, bo może tę kochankę swoją potrafił. Nie wiem. A tutaj panowie są grzeczni, „proszę”, „dziękuję”, „a co lubisz”, „a może tak, a może tak". Zupełnie inaczej się czuje kobieta, taka zadbana się czuje. [k, 45 lat, 2 lata pracy w agencji]

Warto zaznaczyć, że kobiety, które w ten sposób opisywały swoje doświadczenia, były starsze, przyjmowały mniej klientów (zarówno dziennie, jak i w dłuższym czasie) niż ich młodsze koleżanki, deklarowały, iż nie doświadczyły przemocy podczas pracy w agencji. Były więc relatywnie mniej zmęczone (i prawdopodobnie wypalone), a także bardziej przychylnie nastawione do swoich klientów. Ułatwiało im to realizowanie założonej przez nie strategii maksymalizowania własnych doznań seksualnych.

Wbrew potocznym wyobrażeniom, zgodnie z którymi młode, szczególnie atrakcyjne kobiety trafiają do prostytucji, by szukać wrażeń (również seksualnych), te $\mathrm{z}$ nich, które znalazły się w badanej próbie, nie identyfikowały się ze wzorem maksymalizowania swoich doznań. Wręcz odwrotnie - w zasadzie we wszystkich przypadkach prezentowały one dyskurs „tu nie ma przyjemności”. Wiąże się to też z tym, że zwykle miały one wielu klientów, co wynikało zarówno $\mathrm{z}$ ich popularności, jak i strategii polegającej na maksymalnym korzystaniu z nich w danej agencji. Nierzadko były więc zmęczone nie tylko fizycznie, lecz także psychicznie kontaktami z różnymi (również pod względem sposobu ich traktowania) klientami, wypalone, zniechęcone. Odcinanie się od swojego ciała i dążenie do tego, by jak najmniej odczuwać (tak pozytywne, jak i negatywne doznania) podczas stosunku seksualnego $\mathrm{z}$ klientem było ich sposobem na radzenie sobie $\mathrm{z}$ intensywnym doświadczeniem prostytucji.

\section{Wnioski}

Na podstawie przeprowadzonych badań można powiedzieć, że dominującym sposobem relacjonowania swoich doznań podczas komercyjnych stosunków seksualnych przez pracownice agencji jest zaprzeczanie, by odczuwanie orgazmu było 
w ogóle możliwe. Jeśli czasami się to zdarza, to jest to wynik wyjątkowych i rzadko zachodzących okoliczności, które można łatwo wytłumaczyć. Jednocześnie w życiu prywatnym, dzięki więzi emocjonalnej z partnerem, seks jest doświadczeniem przyjemnym i poszukiwanym. Zdecydowanie marginalny charakter miał dyskurs maksymalizowania przyjemności seksualnej podczas seksu z klientem (oraz z partnerem, a więc niezależnie od kontekstu). Był on raczej interpretowany przez rozmówczynie jako pewne wynaturzenie, niewłaściwa reakcja kobiety, która w relacji bezosobowego seksu powinna pozostawać (co najwyżej) obojętna. Może to świadczyć o głębokim zakorzenieniu przekonań dzielących kobiety na „uczciwe” (mające skromne potrzeby seksualne) i „dziwki” (o rozbudzonym popędzie), paradoksalnie aktualnych także w kontekście prostytucji i agencji towarzyskich.

Można również zauważyć, że na sposób doświadczania podczas relacji seksualnych (prywatnych i komercyjnych) wpływa wiele czynników związanych choćby z intensywnością świadczonej pracy seksualnej, ale też z tym, czy partner zna prawdę o pracy w agencji, czy nie, i jak na tę wiedzę reaguje. Może się bowiem zdarzyć, że seks stanie się także w życiu prywatnym kartą przetargową, pozwalającą odpowiednio „rozgrywać” relacje w związku. Można więc wtedy mówić o stosowaniu w życiu prywatnym tych samych mechanizmów, które są efektywne podczas komercyjnych relacji seksualnych (na przykład udawanie orgazmów).

\section{Bibliografia}

Antoniszyn M., Marek A., Prostytucja w świetle badań kryminologicznych, Warszawa 1985.

Becker H., Outsiderzy. Studia z socjologii dewiacji, przeł. O. Siara, Warszawa 2009.

Coy M., „This body which is not mine”. The notion of the habit body, prostitution and (dis)embodiment, „Feminist Theory” 10, 2009, nr 1.

Davidson O'Connell J., Prostitution, Power and Freedom, Cambridge 1998.

Farley M., Kelly V., Prostitution: A critical review of the medical and social sciences literature, „Women \& Criminal Justice" 11, 2000, nr 4.

Glaser B., Strauss A.L., Odkrywanie teorii ugruntowanej, przeł. M. Gorzko, Kraków 2009.

Goffman E., Instytucje totalne. O pacjentach szpitali psychiatrycznych i mieszkańcach innych instytucji totalnych, przeł. O. Waśkiewicz, J. Łaszcz, Sopot 2011.

Goffman E., Piętno. Rozważania o zranionej tożsamości, przeł. A. Dzierżyńska, J. Tokarska-Bakir, Gdańsk 2005.

Hughes E., Careers, „Qualitative Sociology” 20, 1997, nr 3.

Imieliński K., Manowce seksu - prostytucja, Łódź 1990.

Izdebski Z., Seksualność Polaków na początku XXI wieku. Studium badawcze, Kraków 2012.

Izdebski Z., Bartosik G., Kaliwoda A., Zachowanie seksualne i wiedza na temat HIV/AIDS w grupie kobiet świadczacych usługi seksualne, raport TNS OBOP 2002, http://www.aids.gov. pl/badania_spoleczne/228/.

Jasińska M., Proces społecznego wykolejania młodocianych dziewcząt, Warszawa 1967.

Karpiński M., Najstarszy zawód świata. Historia prostytucji, Berkshire 1997.

Konecki K., Praca w koncepcji socjologii interakcjonistycznej, „Studia Socjologiczne” 1, 1988, nr 108. 
Kuryłowicz M., Prawne aspekty prostytucji w państwie rzymskim, [w:] Prostytucja, red. M. Mozgawa, Warszawa 2014.

O'Neill M., Researching prostitution and violence: Towards a feminist praxis, [w:] Women, Violence and Male Power, red. M. Hester, L. Kelly, J. Radford, London 1996.

Oerton S., Phoenix J., Sex/bodywork: Discourses and practices, „Sexualities” 4, 2001.

Rapley T., Analiza konwersacji, dyskursu i dokumentów, przeł. A. Gąsior-Niemiec, Warszawa 2010.

Roberts N., Dziwki w historii: prostytucja w społeczeństwie zachodnim, przeł. L. Engelking, Warszawa 1997.

Rossiaud J., Prostytucja w średniowieczu, przeł. P. Salwa, Warszawa 1997.

Sanders T., 'It's just acting': Sex workers' strategies for capitalizing on sexuality, „Gender, Work and Organization" 12, 2005, $\mathrm{nr} 4$.

Sanders T., The condom as psychological barrier: Female sex workers and emotional management, „Feminism \& Psychology” 12, 2002.

Strauss A., Corbin J., Basics of Qualitative Research, London 1990.

Sztobryn-Giercuszkiewicz J., Psychologiczne aspekty prostytucji, Łódź 2004.

Ślęzak I., Kolektywny wymiar budowania zaangażowania w pracę seksualna kobiet świadczących ustugi seksualne w agencjach towarzyskich, „Przegląd Socjologii Jakościowej” 10, 2014, nr 4.

Ślęzak I., Praca kobiet świadczących usługi seksualne w agencjach towarzyskich, Łódź 2016.

\section{Sexual pleasure experienced by escort agencies' female sex workers — definitions, conditions, contexts}

\section{Summary}

Subject matter of the article is the analysis of manners, which women providing sex services in escort agencies report they experience during commercial sex. Furthermore, the analysis was employed in case of their definition of sexual pleasure in commercial as well as private sex life.

Two reported manners of erotic sensations felt by sex workers during commercial sex can be differentiated. First, the feeling of denial that it is possible to feel pleasure in this context. Orgasm experienced by escort agencies' employees is presented as a myth developed for the clients' needs. The second thing, the sex workers can and do feel sexual pleasure during meetings with clients. According to a part of the researched women, the denial that satisfying relations with clients do not take place is the myth. Both perspectives were compared with accounts of those women regarding their sex lives.

An empirical basis for the article is posed by data collected within the scope of the qualitative research project carried out in escort agencies in Łódź. 